\title{
Industry Impact of Covid Epidemic based on Event Analysis
}

\author{
Zhiqiang Li \\ School of Statistics, Shandong Technology and Business University, Yantai, China \\ ccecstat@sina.com
}

\begin{abstract}
On the day of the outbreak, the Covid epidemic brought huge systemic risks in China stock market, which even offset the positive effects brought about by the epidemic. For example, industries such as medicine did not show the expected general rise on the day of the epidemic. After the outbreak, with the rapid intervention of the government, investor confidence regained and they had high hopes for the market outlook. The market rebounded quickly and returned to the preepidemic level in less than 10 days. However, the performance of various industries in this process is different. This paper examines the impact of Covid epidemic on various industries in China based on the event analysis method.
\end{abstract}

Keywords: Event Study; Covid Epidemic; Industry Impact.

\section{Introduction}

A sudden epidemic disrupted the normal order of society and brought shocks to economic system. The most rapid and direct manifestation of the impact of emergencies on the economy appears in the stock market. The impact of emergencies on the stock market has significant characteristics. First of all, the impact of emergencies on the stock market often takes the form of an impulse effect, the impact has an immediate effect, and the instantaneous impact is large. Secondly, the impulse effect of emergencies on the stock market may disappear in a short time, or it may last for a long time. The resilience to the impact of emergencies represents the robustness of the market system. Generally speaking, the market in a developed region has a stronger resilience to impacts, and a market in an developing region is less resistant to impacts. Therefore, it can be said that the market's recovery from impacts represents the perfection of the market. After an emergency occurs, the government's handling of the incident and fiscal and monetary policy responses also play a key role in the recovery of the market.

The risk of the stock market is composed of systemic risk and non-systematic risk. Unexpected events may cause turbulence in the entire market, which is a manifestation of systemic risks. However, the impact of emergencies on each stock is different. For example, an earthquake may be a disaster for transportation stocks, but it may also be a benefit for infrastructure stocks. The non-systematic risks caused by emergencies are different. Therefore, it is meaningful to compare and analyze the impact of the epidemic crisis on stocks in different industries. In previous results, we did not find similar results.

\section{Review of Related Literature}

Out of the need to respond to the crisis, the academic community has always paid attention to the impact of emergencies on the economic system, and to some extent assessed the economic system's resilience to the shock. Among the research methods on the impact of emergencies on the capital market, the focus of the event analysis method is to determine the abnormal returns that a particular event brings to a certain company's stock (Ayman Mnasri and Salem Nechi, 2016). In order to capture the impact of unexpected events on the stock market shock, Brown and Warner (1985) defined abnormal returns to measure the size and duration of the deviation from the past average of returns, and most of the subsequent studies continued this method. The event analysis method believes that if investors respond well to abnormal events, we expect that stocks will have positive abnormal returns before and after the event. On the contrary, if investors react adversely to events, we expect that stocks will have negative abnormal returns (Andrew Chen, Thomas Siems, 2004). 
Andrew Chen and Thomas Siems (2004) used event research methods to examine the response of the U.S. and global capital markets to multiple terrorist attacks, and found that the U.S. capital market is more resilient than other markets and is more resilient to terrorist attacks than other capital markets. And this strong market flexibility can be partly explained by the stable financial sector, which provides sufficient liquidity to promote market stability and minimize panic. Christos Kollias et al. (2011) found that similar bomb terrorist incidents had significant negative abnormal returns in various industries in Spain, but not in England, and the London market rebounded much faster. Ayman Mnasri and Salem Nechi (2016) found that the volatility caused by terrorist attacks in the markets in the Middle East and North Africa lasted as long as 20 trading days, which was much higher than that in developed markets. There are not many domestic studies using the event analysis method. Tao Ping and Liu Xianwei (2015) found that foreign emergencies can significantly affect the domestic stock market, and the A-share market activity and rate of return are significantly different before and after the event. Zhao Jingmei et al. (2014) found that domestic natural disasters and man-made disasters have caused a significant negative impact on the stock prices of listed companies in the region.

Continuing the research ideas of the predecessors, this article first verifies the impact of the epidemic on China's stock market. Unlike the predecessors, this article does not verify the impact of the epidemic on the entire market, but verifies the impact of the epidemic on various industries. The impact of the epidemic on different industries was tested. At the same time, it focused on the recovery of various industries after the crisis.

\section{Methodolog}

Event analysis method is based on the efficient market hypothesis, when the market when there is new information that investors assess the impact of this information on the company's future operations, re-evaluate the value of their shares, to buy or sell in the market, so that the new information on the company The impact of this is immediately reflected in the changes in stock prices. The event analysis method considers that a significant positive or negative stock price change corresponds to a specific abnormal event. If this significant stock price change can be identified, the impact of the abnormal event on the stock can be assessed.

The abnormal stock price change is realized by capturing the abnormal return of the stock price. There are many ways to calculate the abnormal return on stock prices. One method calculates the deviation between the stock return and the average historical return of the stock to get the abnormal return on the stock. The calculation formula is as follows.

$$
A R_{i t}=R_{i t}-\bar{R}_{i}
$$

In the formula, $A R_{i t}$ is the abnormal return rate of the $\mathrm{i}$-th stock, $R_{i t}$ is the actual observed return rate, and $\bar{R}_{i}$ is the historical average return rate.

Another method of abnormal stock price returns comes from the market model, which believes that stock returns maintain a stable linear relationship with market portfolio returns, and the deviation of stock returns from this linear relationship can be measured to get the stock's abnormal returns. The calculation formula is as follows

$$
A R_{i t}=R_{i t}-\left[\alpha_{i}+\beta_{i} R_{m, t}\right]
$$

In the formula, $A R_{i t}$ is the abnormal return rate of the $\mathrm{i}$-th stock, $R_{i t}$ is the actual observed return rate, $R_{m, t}$ is the market portfolio return rate, usually the return rate of a certain market composite index, $\alpha_{i}$ and $\beta_{i}$ are the intercept and slope of the $\mathrm{i}$-th stock linear market model. 
This paper uses the former method to calculate the abnormal rate of return, where the historical average rate of return $\bar{R}_{i}$ uses the historical average to adjust the rate of return. The calculation formula is as follows

$$
\bar{R}_{i}=\frac{1}{20} \sum_{t=-30}^{-11} R_{i t}
$$

In addition to calculating the impact of the abnormal event on the stock price on the day of the occurrence, it is also necessary to study the continuous response of the stock price after the abnormal shock occurs, which requires calculating the cumulative abnormal return rate of the stock after the abnormal shock. Calculated as follows

$$
C A R_{i}=\sum_{t=t_{0}}^{\mathrm{t}_{1}} A R_{i t}
$$

In the formula, $C A R_{i}$ is the cumulative abnormal return rate of the $\mathrm{i}$-th stock, $t_{0}$ is the day when the abnormal event occurs, and $t_{1}$ is the $t_{1}$ day after the abnormal event occurs.

In order to test the significance of the abnormal rate of return and the cumulative abnormal rate of return, the two rates of return need to be tested. Here the $T$ test is used to test the significance of the two returns. The test statistics are defined as follows

$$
\begin{gathered}
t_{A R}=\frac{A R}{s(A R)} \\
t_{C A R}=\frac{C A R}{s(C A R)}
\end{gathered}
$$

\section{Data and Some Explain}

The data in this article comes from the Flush stock trading software. There are 66 industry classifications in China stock market. We extracted the closing data of 66 industry indexes and converted them into logarithmic return data. Our interception of industry index closing data is from May 6, 2019 to April 10, 2020. The reason for such interception is that China stock market has just experienced a wave of policy fluctuations before this period, which may affect our analysis, and there was no obvious shock event in the stock market after that, which met our analysis conditions.

Although there have been rumors and reports of the epidemic before, taking into account the public's awareness of the epidemic, we took January 23, 2020, the date the government announced the closure of Wuhan as the date of the epidemic. Since the announcement of the closure of the city has exceeded the trading hours of the day, we believe that the first impact of the epidemic on the stock market will occur on the next trading day, February 3.

\section{Analysis Process and Results}

\subsection{Test for Market Effectiveness}

Market efficiency is necessary for event analysis methods. Therefore, we first tested the effectiveness of the Chinese stock market. We used Box-Pierce test and Ljung-Box test to test the autocorrelation of the logarithmic return series of the entire market indexes and 66 industry indexes, and found that all logarithmic return series conform to the white noise characteristics. 


\subsection{Instant Response to the Epidemic in Various Industries}

Table 1. Abnormal return of various industry indexes on the epidemic day

\begin{tabular}{|c|c|c|c|c|c|c|c|c|}
\hline Industry & \multicolumn{2}{|c|}{ Abnormal return } & Industry & \multicolumn{2}{|c|}{ Abnormal return } & Industry & \multicolumn{2}{|c|}{ Abnormal return } \\
\hline $\begin{array}{c}\text { Pharmaceutical } \\
\text { business }\end{array}$ & $0.38 \%$ & $(-0.1956)$ & $\begin{array}{c}\text { Other } \\
\text { electronics }\end{array}$ & $-9.47 \%$ & $(-3.7674)$ & $\begin{array}{c}\text { Electronics } \\
\text { manufacturing }\end{array}$ & $-9.91 \%$ & $(-3.6429)$ \\
\hline $\begin{array}{l}\text { Medical } \\
\text { equipment } \\
\text { services }\end{array}$ & $-1.01 \%$ & $(-0.4797)$ & $\begin{array}{l}\text { Agricultural } \\
\text { services }\end{array}$ & $-9.49 \%$ & $(-3.5336)$ & Steel & $-9.93 \%$ & $(-4.4548)$ \\
\hline $\begin{array}{l}\text { Traditional } \\
\text { Chinese } \\
\text { medicine }\end{array}$ & $-2.54 \%$ & $(-1.2188)$ & chemicals & $-9.50 \%$ & $(-4.1710)$ & $\begin{array}{c}\text { Auto parts } \\
\text { manufacturing }\end{array}$ & $-9.98 \%$ & $(-4.1992)$ \\
\hline $\begin{array}{l}\text { Chemical and } \\
\text { pharmaceutical }\end{array}$ & $-3.35 \%$ & $(-1.6218)$ & $\begin{array}{l}\text { Non-ferrous } \\
\text { smelting } \\
\text { processing }\end{array}$ & $-9.52 \%$ & $(-4.0484)$ & $\begin{array}{l}\text { Computer } \\
\text { equipment }\end{array}$ & $-9.98 \%$ & $(-3.5551)$ \\
\hline $\begin{array}{l}\text { Biological } \\
\text { Products }\end{array}$ & $-3.74 \%$ & $(-1.7997)$ & $\begin{array}{l}\text { Hotel and } \\
\text { Catering }\end{array}$ & $-9.55 \%$ & $(-3.9905)$ & $\begin{array}{l}\text { Building } \\
\text { Decoration }\end{array}$ & $-10.02 \%$ & $(-4.4237)$ \\
\hline Comprehensive & $-7.14 \%$ & $(-3.3504)$ & $\begin{array}{c}\text { Beverage } \\
\text { manufacturing }\end{array}$ & $-9.55 \%$ & $(-4.3048)$ & Port shipping & $-10.09 \%$ & $(-4.6796)$ \\
\hline $\begin{array}{l}\text { Chemical } \\
\text { synthetic } \\
\text { materials }\end{array}$ & $-7.37 \%$ & $(-3.3647)$ & $\begin{array}{l}\text { Extraction } \\
\text { Services }\end{array}$ & $-9.58 \%$ & $(-3.9875)$ & $\begin{array}{l}\text { Computer } \\
\text { application }\end{array}$ & $-10.09 \%$ & $(-3.6410)$ \\
\hline $\begin{array}{c}\text { Textile } \\
\text { manufacturing }\end{array}$ & $-7.97 \%$ & $(-3.7053)$ & Aquaculture & $-9.66 \%$ & $(-3.5761)$ & $\begin{array}{c}\text { Insurance and } \\
\text { others }\end{array}$ & $-10.11 \%$ & $(-4.1200)$ \\
\hline Bank & $-7.97 \%$ & $(-4.1763)$ & Retail & $-9.68 \%$ & $(-4.4051)$ & $\begin{array}{c}\text { General } \\
\text { Equipment }\end{array}$ & $-10.12 \%$ & $(-4.3762)$ \\
\hline $\begin{array}{c}\text { Basic } \\
\text { Chemistry }\end{array}$ & $-8.11 \%$ & $(-3.6942)$ & Electricity & $-9.69 \%$ & $(-4.7384)$ & $\begin{array}{l}\text { Packaging and } \\
\text { Printing }\end{array}$ & $-10.13 \%$ & $(-4.3726)$ \\
\hline Apparel Textile & $-8.30 \%$ & $(-3.7580)$ & $\begin{array}{c}\text { Household } \\
\text { Light Industry }\end{array}$ & $-9.70 \%$ & $(-4.3327)$ & $\begin{array}{l}\text { Petroleum } \\
\text { mining }\end{array}$ & $-10.19 \%$ & $(-4.3358)$ \\
\hline $\begin{array}{l}\text { New chemical } \\
\text { materials }\end{array}$ & $-8.54 \%$ & $(-3.7351)$ & $\begin{array}{c}\text { Airport } \\
\text { shipping }\end{array}$ & $-9.70 \%$ & $(-4.4140)$ & $\begin{array}{c}\text { Communication } \\
\text { device }\end{array}$ & $-10.19 \%$ & $(-3.7394)$ \\
\hline $\begin{array}{l}\text { Food } \\
\text { processing and } \\
\text { manufacturing }\end{array}$ & $-8.66 \%$ & $(-3.7396)$ & $\begin{array}{l}\text { Coal mining } \\
\text { and } \\
\text { processing }\end{array}$ & $-9.70 \%$ & $(-4.3573)$ & Bus & $-10.26 \%$ & $(-4.4357)$ \\
\hline $\begin{array}{c}\text { Communication } \\
\text { services }\end{array}$ & $-8.82 \%$ & $(-3.2529)$ & $\begin{array}{l}\text { Road and rail } \\
\text { transport }\end{array}$ & $-9.71 \%$ & $(-4.8033)$ & $\begin{array}{c}\text { Park } \\
\text { development }\end{array}$ & $-10.27 \%$ & $(-4.4945)$ \\
\hline Media & $-8.86 \%$ & $(-3.5786)$ & $\begin{array}{l}\text { Attractions } \\
\text { and Tourism }\end{array}$ & $-9.72 \%$ & $(-4.0821)$ & Instrumentation & $-10.28 \%$ & $(-3.9885)$ \\
\hline Logistics & $-8.96 \%$ & $(-4.0247)$ & $\begin{array}{l}\text { Vehicle } \\
\text { production }\end{array}$ & $-9.74 \%$ & $(-3.9922)$ & Securities & $-10.28 \%$ & $(-4.0017)$ \\
\hline $\begin{array}{l}\text { Processing of } \\
\text { agricultural } \\
\text { products }\end{array}$ & $-9.02 \%$ & $(-3.6740)$ & $\begin{array}{l}\text { Building } \\
\text { materials }\end{array}$ & $-9.79 \%$ & $(-4.2796)$ & $\begin{array}{l}\text { National } \\
\text { Defense } \\
\text { Industry }\end{array}$ & $-10.34 \%$ & $(-3.9721)$ \\
\hline Trading & $-9.12 \%$ & $(-4.2112)$ & $\begin{array}{c}\text { Electrical } \\
\text { Equipment }\end{array}$ & $-9.81 \%$ & $(-4.1660)$ & $\begin{array}{l}\text { Environmental } \\
\text { Engineering }\end{array}$ & $-10.59 \%$ & $(-4.3873)$ \\
\hline Papermaking & $-9.19 \%$ & $(-3.9755)$ & $\begin{array}{l}\text { Plantation and } \\
\text { Forestry }\end{array}$ & $-9.81 \%$ & $(-3.3868)$ & Optoelectronics & $-10.61 \%$ & $(-4.0520)$ \\
\hline $\begin{array}{c}\text { Audiovisual } \\
\text { equipment }\end{array}$ & $-9.25 \%$ & $(-3.7807)$ & $\begin{array}{l}\text { Professional } \\
\text { setting }\end{array}$ & $-9.86 \%$ & $(-4.3191)$ & $\begin{array}{l}\text { Semiconductors } \\
\text { and components }\end{array}$ & $-10.85 \%$ & $(-3.7429)$ \\
\hline White goods & $-9.41 \%$ & $(-4.2697)$ & $\begin{array}{c}\text { Real estate } \\
\text { development }\end{array}$ & $-9.87 \%$ & $(-4.5789)$ & New material & $-10.94 \%$ & $(-4.3236)$ \\
\hline $\begin{array}{l}\text { Delivery } \\
\text { equipment } \\
\text { services }\end{array}$ & $-9.43 \%$ & $(-4.2228)$ & $\begin{array}{l}\text { Gas and } \\
\text { Water }\end{array}$ & $-9.91 \%$ & $(-4.6684)$ & $\begin{array}{l}\text { Non-vehicle } \\
\text { transportation }\end{array}$ & $-11.57 \%$ & $(-4.7668)$ \\
\hline
\end{tabular}

${ }^{\mathrm{a}} \mathrm{T}$-test statistics in parentheses

Today, when information is highly developed, the impact of emergencies on the stock market will immediately be reflected in changes in stock prices. Because investors believe that emergencies have 
different impacts on various industries, they adopt different buying and selling measures for stocks in different industries. As a result, stocks in various industries respond differently to the epidemic. For example, it is generally believed that similar epidemics will affect business and transportation stocks are bad news, but it may be good news for pharmaceutical stocks. Here we have calculated the abnormal return rate of each industry index on the day of the outbreak and tested its significance.

It can be seen from Table 1 that on the first trading day after the outbreak, the stock market suffered an extraordinary shock, and the stock prices of most industries fell severely. Except for the five industries related to medicine and biological vaccines, other industries have negative abnormal return rates of more than 7\%. Even life service industries such as food processing, beverages, and gas and water services are not immune. As the Chinese stock market has price limit restrictions, it can be judged that a considerable number of industry stocks have reached the price limit position. Based on the stock market's decline regardless of the magnitude of the industry, it can be inferred that the stock market on the day of the epidemic was a panic selling. The t-test results of 5 industries other than medicine and biological vaccines also showed that these negative abnormal returns passed the significance test.

In addition to having a huge and unusual impact on most industries, there are five unique industries. These are the five medical and pharmaceutical industries in the pharmaceutical business, medical equipment services, traditional Chinese medicine, chemical medicine and biological products industries. In these five industries, although the positive abnormal return rate of the pharmaceutical business was $0.38 \%$, its significance did not pass the $t$ test. The abnormal returns of the remaining four industries are all negative, but the significance of the abnormal returns has not yet passed the $t$ test. Under normal circumstances, the emergence of this epidemic should be good news for medical and pharmaceutical companies. However, on the day of the epidemic, the impact of the epidemic on the medical and pharmaceutical industries was ambiguous, that is, the overall situation did not increase as usual, nor did it decline sharply like other trends. Analyzing the reason, it may be that the panic caused by the huge impact of the abnormal event overwhelmed the rational judgment of investors. The fear of market risks hinders investors' pursuit of additional benefits.

\subsection{Follow-up Performance of Various Industries}

The day of the epidemic brought huge systemic risks to the market. However, if the market does not collapse and the government intervenes in the stock market, investors expect the market to reverse and the stock market will show a recovery, but the speed and intensity of the recovery will vary from industry to industry. Therefore, it is more important to analyze the market recovery after the outbreak . In the following analysis, in order to check the stock price recovery of various industries after the outbreak of the epidemic, we calculated the cumulative abnormal return rate of the industry for 5 and 10 days after the outbreak. The results are shown in Table 2:

Table 2. Abnormal return rate of the industry for 5 and 10 days after the outbreak

\begin{tabular}{|c|c|c|c|c|c|c|c|c|c|}
\hline Industry & \multicolumn{2}{|c|}{5 -day CAR } & \multicolumn{2}{|c|}{ 10-day CAR } & \multicolumn{2}{|c|}{ Industry } & \multicolumn{2}{|c|}{5 -day CAR } & \multicolumn{2}{|c|}{ 10-day CAR } \\
\hline $\begin{array}{c}\text { Semiconductors } \\
\text { and components }\end{array}$ & $11.71 \%$ & $(1.65)$ & $16.47 \%$ & $(1.71)$ & $\begin{array}{c}\text { Food processing } \\
\text { and } \\
\text { manufacturing }\end{array}$ & $13.80 \%$ & $(2.43)$ & $7.31 \%$ & $(0.95)$ \\
\hline $\begin{array}{c}\text { Computer } \\
\text { equipment }\end{array}$ & $14.87 \%$ & $(2.16)$ & $15.82 \%$ & $(1.70)$ & Instrumentation & $10.26 \%$ & $(1.62)$ & $7.30 \%$ & $(0.85)$ \\
\hline $\begin{array}{c}\text { Other } \\
\text { electronics }\end{array}$ & $16.52 \%$ & $(2.68)$ & $15.46 \%$ & $(1.86)$ & $\begin{array}{c}\text { Building } \\
\text { materials }\end{array}$ & $9.87 \%$ & $(1.76)$ & $7.28 \%$ & $(0.96)$ \\
\hline $\begin{array}{c}\text { Planting and } \\
\text { forestry }\end{array}$ & $16.71 \%$ & $(2.35)$ & $15.40 \%$ & $(1.60)$ & Logistics & $9.52 \%$ & $(1.75)$ & $7.12 \%$ & $(0.97)$ \\
\hline $\begin{array}{c}\text { Computer } \\
\text { application }\end{array}$ & $16.96 \%$ & $(2.50)$ & $15.33 \%$ & $(1.67)$ & Securities & $7.88 \%$ & $(1.25)$ & $6.94 \%$ & $(0.82)$ \\
\hline $\begin{array}{c}\text { Medical } \\
\text { equipment } \\
\text { services }\end{array}$ & $21.11 \%$ & $(4.08)$ & $15.07 \%$ & $(2.15)$ & $\begin{array}{c}\text { General } \\
\text { Equipment }\end{array}$ & $9.82 \%$ & $(1.73)$ & $6.43 \%$ & $(0.84)$ \\
\hline
\end{tabular}




\begin{tabular}{|c|c|c|c|c|c|c|c|c|c|}
\hline $\begin{array}{l}\text { Communication } \\
\text { services }\end{array}$ & $18.20 \%$ & (2.74) & $15.00 \%$ & (1.67) & $\begin{array}{l}\text { Packaging and } \\
\text { Printing }\end{array}$ & $10.93 \%$ & (1.93) & $6.15 \%$ & $(0.80)$ \\
\hline $\begin{array}{l}\text { Biological } \\
\text { Products }\end{array}$ & $20.67 \%$ & (4.06) & $13.48 \%$ & (1.96) & Papermaking & $11.12 \%$ & $(1.96)$ & $5.43 \%$ & $(0.71)$ \\
\hline $\begin{array}{l}\text { Chemical and } \\
\text { pharmaceutical }\end{array}$ & $19.17 \%$ & (3.79) & $12.79 \%$ & $(1.87)$ & $\begin{array}{l}\text { Non-vehicle } \\
\text { transportation }\end{array}$ & $9.37 \%$ & $(1.58)$ & $5.40 \%$ & $(0.67)$ \\
\hline $\begin{array}{l}\text { Processing of } \\
\text { Agricultural } \\
\text { products }\end{array}$ & $16.57 \%$ & $(2.75)$ & $12.59 \%$ & $(1.55)$ & $\begin{array}{l}\text { Vehicle } \\
\text { production }\end{array}$ & $7.64 \%$ & $(1.28)$ & $5.37 \%$ & $(0.66)$ \\
\hline New material & $0.92 \%$ & $1.76)$ & $1.42 \%$ & $1.36)$ & Steel & $.55 \%$ & $1.57)$ & $4.91 \%$ & $0.66)$ \\
\hline $\begin{array}{c}\text { Agricultural } \\
\text { services }\end{array}$ & $18.74 \%$ & $(2.85)$ & $11.24 \%$ & $(1.26)$ & Apparel Textile & $11.34 \%$ & (2.09) & $4.64 \%$ & $(0.63)$ \\
\hline $\begin{array}{c}\text { communication } \\
\text { device }\end{array}$ & $12.02 \%$ & $(1.80)$ & $10.78 \%$ & $(1.19)$ & Airport shipping & $8.53 \%$ & $(1.58)$ & $4.64 \%$ & $(0.64)$ \\
\hline $\begin{array}{c}\text { Audiovisual } \\
\text { equipment }\end{array}$ & $13.36 \%$ & $(2.23)$ & $10.38 \%$ & (1.28) & $\begin{array}{c}\text { Real estate } \\
\text { development }\end{array}$ & $6.63 \%$ & $(1.25)$ & $4.46 \%$ & $(0.62)$ \\
\hline Chemicals & $12.30 \%$ & $(2.20)$ & $10.35 \%$ & $(1.37)$ & Insurance & $6.17 \%$ & $(1.03)$ & $4.42 \%$ & $(0.54)$ \\
\hline Media & 180 & 6 & & $.25)$ & & & & & .70) \\
\hline $\begin{array}{l}\text { National } \\
\text { Defense } \\
\text { Industry }\end{array}$ & $9.96 \%$ & (1.56) & $9.97 \%$ & $(1.15)$ & $\begin{array}{r}\text { Deliv } \\
\text { equip } \\
\text { servi }\end{array}$ & $8.36 \%$ & (1.53) & $3.93 \%$ & $(0.53)$ \\
\hline White goods & $13.44 \%$ & (2.49) & $9.87 \%$ & $(1.35)$ & $\begin{array}{r}\text { Coal m } \\
\text { proc }\end{array}$ & $7.34 \%$ & $(1.35)$ & $3.76 \%$ & $(0.51)$ \\
\hline $\begin{array}{c}\text { Pharmaceutical } \\
\text { business }\end{array}$ & $19.31 \%$ & $(4.05)$ & $9.44 \%$ & (1.46) & $\begin{array}{r}\text { Petr } \\
\mathrm{mi}\end{array}$ & $8.77 \%$ & $(1.52)$ & $3.60 \%$ & $(0.46)$ \\
\hline $\begin{array}{c}\text { Electronics } \\
\text { manufacturing }\end{array}$ & $9.82 \%$ & (1.47) & $9.15 \%$ & $(1.01)$ & Gas and Water & $9.43 \%$ & $(1.81)$ & $3.52 \%$ & $(0.50)$ \\
\hline $\begin{array}{l}\text { Non-ferrous } \\
\text { smelting } \\
\text { processing }\end{array}$ & $9.72 \%$ & (1.69) & $9.10 \%$ & (1.17) & $\begin{array}{l}\text { Household } \\
\text { Light Industry }\end{array}$ & $7.68 \%$ & $(1.40)$ & $3.44 \%$ & $(0.46)$ \\
\hline $\begin{array}{l}\text { Chemical } \\
\text { synthetic } \\
\text { materials }\end{array}$ & $13.56 \%$ & $(2.53)$ & $9.02 \%$ & (1.24) & $\begin{array}{l}\text { Attractions and } \\
\text { Tourism }\end{array}$ & $7.72 \%$ & $(1.32)$ & $3.30 \%$ & $(0.42)$ \\
\hline Comp & & & & & & & & & $0.41)$ \\
\hline $\begin{array}{c}\text { Textile } \\
\text { manufacturing }\end{array}$ & $16.92 \%$ & (3.21) & $8.65 \%$ & $(1.21)$ & Buil & $7.18 \%$ & $(1.29)$ & $2.93 \%$ & $(0.39)$ \\
\hline $\begin{array}{l}\text { Traditional } \\
\text { Chinese } \\
\text { medicine }\end{array}$ & $16.45 \%$ & (3.23) & $8.56 \%$ & $(1.24)$ & $\begin{array}{l}\text { Extraction } \\
\text { Service }\end{array}$ & $5.85 \%$ & $(0.99)$ & $2.89 \%$ & $(0.36)$ \\
\hline $\begin{array}{c}\text { Environmental } \\
\text { Engineering }\end{array}$ & $15.73 \%$ & (2.66) & $8.50 \%$ & $(1.06)$ & Electricity & $7.62 \%$ & $(1.52)$ & $2.85 \%$ & $(0.42)$ \\
\hline $\begin{array}{c}\text { Animal } \\
\text { breeding }\end{array}$ & $14.23 \%$ & (2.15) & $8.10 \%$ & $(0.90)$ & Trading & $7.51 \%$ & $(1.42)$ & $2.17 \%$ & $(0.30)$ \\
\hline $\begin{array}{l}\text { New chemical } \\
\text { materials }\end{array}$ & $12.33 \%$ & $(2.20)$ & $8.06 \%$ & $(1.06)$ & $\begin{array}{l}\text { Development } \\
\text { zone }\end{array}$ & $7.37 \%$ & $(1.32)$ & $2.16 \%$ & $(0.28)$ \\
\hline Basic Chemistry & $13.48 \%$ & $(2.51)$ & $8.06 \%$ & (1.11) & $\begin{array}{c}\text { Road and rail } \\
\text { transport }\end{array}$ & $7.98 \%$ & $(1.61)$ & $1.49 \%$ & $(0.22)$ \\
\hline Optoelectronics & $8.70 \%$ & (1.36) & $7.95 \%$ & $(0.92)$ & $\begin{array}{r}\text { Beve } \\
\text { manufa }\end{array}$ & $6.30 \%$ & $(1.16)$ & $1.38 \%$ & $(0.19)$ \\
\hline $\begin{array}{c}\text { Professional } \\
\text { setting }\end{array}$ & $10.67 \%$ & (1.91) & $7.93 \%$ & $(1.05)$ & $\begin{array}{c}\text { Hotel and } \\
\text { Catering }\end{array}$ & $5.15 \%$ & $(0.88)$ & $0.94 \%$ & $(0.12)$ \\
\hline $\begin{array}{c}\text { Auto parts } \\
\text { manufacturing }\end{array}$ & $11.52 \%$ & (1.98) & $7.45 \%$ & $(0.94)$ & Port shipping & $3.72 \%$ & $(0.70)$ & $-0.69 \%$ & $(0.10)$ \\
\hline $\begin{array}{l}\text { Electrical } \\
\text { Equipment }\end{array}$ & $9.29 \%$ & (1.61) & $7.31 \%$ & $(0.94)$ & $\begin{array}{c}\text { Public } \\
\text { transportation }\end{array}$ & $3.25 \%$ & $(0.57)$ & $-1.48 \%$ & $(0.19)$ \\
\hline
\end{tabular}

${ }^{\mathrm{a}}$ T-test statistics in parentheses

From Table 2, we can see that 5 days after the outbreak, the abnormal return rates of all industries are positive, and more than half of the industry's abnormal return rates have passed the significance 
t-test. This shows that after the outbreak of the epidemic, stock prices in all industries quickly stopped falling abnormally, and at least half of the industries began a retaliatory rebound. As for the main reason for the rapid recovery of the stock market after the outbreak of the epidemic, our analysis believes that the government's market stabilization policies and measures have restored investor confidence, thereby eliminating investor panic when the epidemic first appeared. Due to the excessive release of systemic risks on the day of the epidemic, most stock prices fell abnormally.

When analyzing the recovery of various industries in the market after the outbreak of the epidemic, we also found some important phenomena. The first is the complete release of the positive effects of the epidemic in the medical and pharmaceutical industries. Within five days after the outbreak, the cumulative abnormal return rate of the five pharmaceutical industries was $16.45 \%$, with the highest being $21.11 \%$, and all passed the significance $t$ test. Second, in addition to the medical and pharmaceutical industries, the stock prices of electronics, chemicals, textiles, agricultural products processing, food processing and manufacturing, and aquaculture also showed significant positive abnormal returns. The first three types of these lists are the advantages of my country's manufacturing industry. This industry is also a relatively active industry in the stock market. The last three industries are closely related to the production and service of mass food. Except for the medical industry, these industries should be the first to recover in the market.

Analyzing the cumulative abnormal return 10 days after the outbreak date, we found a different phenomenon from the cumulative abnormal return 5 days after the outbreak. First, the cumulative abnormal return 10 days after the outbreak date in most industries is less than the cumulative abnormal return 5 days after the outbreak date, which indicates that the market has further recovered its rationality. At the same time, in the cumulative abnormal return rate of 10 days after the outbreak of the epidemic, only the medical device service industry and the biological product industry have obvious positive abnormal return rates. Although most abnormal returns in other industries are still positive, they are not significance in the t-test. This shows that with the exception of the two pharmaceutical industries, the abnormal rate of return in the entire market has basically disappeared, and the market will gradually return to the state before the outbreak. The epidemic no longer has a systemic impact on the stock market.

Chen (2004) found that after the emergencies, the financial sector of Bank of America played a significant role in the stability of the market. The financial banking industry took measures to increase government flows, and stock prices quickly recovered from the downturn in the market. Here, we checked the indexes representing the banking, securities and insurance industries in the financial industry in the Chinese market, and found that the indexes of these three industries performed generally after the outbreak. The cumulative abnormal returns of 5-day and 10-day are both negligible positive returns, far inferior to other outstanding industries. There is no significant difference in the number of days for these three industry indexes to return to pre- epidemic levels. Some explanation can be given here. One is that the financial industry (industry) has not played an important intermediary role in the increase in liquidity, and the other is that Chinese investors are more concerned about fiscal policy than financial policy.

\section{Conclusion}

Historically, it is inevitable that emergencies will cause market sentiment panic and cause violent fluctuations in the capital market. The ability to quickly recover from this panic volatility is a sign of the maturity of a market. After analyzing the impact of the epidemic, we found that although the stock market fell sharply on the day of the epidemic, it recovered quickly and returned to the pre-epidemic level in about ten days. It did not cause a long-term downward trend under the systemic shock as before. It shows that the Chinese stock market has a strong ability to resist systemic risks.

In addition, we also found that the impact of the epidemic on various industries is different. After the outbreak of the epidemic, the stock prices of the medical and pharmaceutical industries have continued to rise. Some advantageous industries such as electronics and chemicals, as well as food 
processing, planting and breeding, are related to food consumption. In the industry, stock prices have also rebounded rapidly, even surpassing the level before the epidemic.

\section{References}

[1] Jingmei Zhao, Yu Shen, Fengyun Wu. Natural disasters and social violence's events and stock prices [J]. Journal of Management Sciences in China,2014,17(4):19-33.

[2] Ping Tao, Xianwei Liu. Research on the Impacts of Unexpected Events Abroad on Domestic Stock Market [J]. Forecasting,2015, 34(2):66-70.

[3] Andrew H. Chen, Thomas F. Siems. The effects of terrorism on global capital markets[J]. European Journal of Political Economy. 2004 (20): 349-366.

[4] Ayman Mnasri, Salem Nechi. Impact of terrorist attacks on stock market volatility in emerging markets[J] Emerging Markets Review. 2016 (28): 184-202.

[5] Brown, S.J., Warner, J.B. Using daily stock returns: the case of event studies. Journal of Financial Economics [J]. 1985 (14): 3-31.

[6] Christos Kollias, Stephanos Papadamou, Apostolos Stagiannis. Terrorism and capital markets: The effects of the Madrid and London bomb attacks[J]. International Review of Economics and Finance.2011 (20): $532-541$. 